\title{
BOOK REVIEW THE POVERTY OF TERRITORIALISM. A NEO-MEDIEVAL VIEW OF EUROPE AND EUROPEAN PLANNING
}

Andreas Faludi

Cheltenham, Northampton: Edward Elgar, 2018

200 pages, ISBN 9781788973601

\author{
Jacek Zaucha (D) \\ Faculty of Economics, University of Gdańsk \\ Armii Krajowej 119, 81-701 Sopot: Poland \\ jacek.zaucha@gmail.com
}

In his recent book ${ }^{1}$, Faludi - one of the most innovative and non-schematic contemporary researchers and observers of the European spatial realm - summarises and shares his experience on key issues related to space, and the latter's role and significance in governance in the European context. At first glance, this book might appear to be a routine task for a scholar of such calibre, but it is far from a typical scientific resume. On the contrary, this book is a breathtaking read, full of smart anecdotes and unexpected real-life examples that greatly illustrate the author's thinking, rich with historical parallels and universal parabolas. Each page and chapter speaks to the reader and contains such passion and strength that one might very well gain the impression of participating in a real-time personal chat with the author. Of course, this is on purpose. Through this dynamic and seemingly interactive narrative style, Faludi tries to convey significant information regarding space, as well as the future of the European project itself. He looks ahead into the coming decades, identifies potential key frictions and inconsistencies and horns a warning bell, challenging, not only our stereotypes, but also several crucial axioms underpinning the spatial sciences.

And who, if not Faludi, has the right and intellectual capacity to do that? Born in Hungary, brought up in Austria, sharing his professional life between universities in the UK and the Netherlands, Faludi belongs to the new category of global citizens who identify themselves more with ideas and issues than with the territory or power of nation-states. He is quite aware of his uniqueness in this regard (Faludi 2010: IX-XI), being part of a "roving band of planners", who put an immense amount of effort into the progression of European-type thinking and Europeanisation. As a propagator of a European Model of Society (Faludi 2007), as formulated by Jacques Delors and others, Faludi is aware of the key informal mechanisms and syndromes constituting and sustaining the EU as a mental process. His main message in the present book can be sum-

\footnotetext{
${ }^{1}$ The eBook version is available at Google Play, ebooks.com and other eBook vendors, while in print the book can be ordered from the Edward Elgar Publishing website (https://www.e-elgar.com/).
} 
marised as follows: "Read my lips, no more territorialism" (Faludi 2018: 65) and "territorialism is the opiate of the masses" (Faludi 2018: 21). In particular he warns against territorialism "writ large', at EU level.

Indeed, Faludi puts the entire concept of territoriality under question. By doing so, he echoes a famous poem by Zbigniew Herbert, entitled "Meditation on the National Problem" that summarises the dilemmas experienced by Poles in regard to territoriality. Herbert raises serious doubts in and around the idea that "the use of the same curses and similar love entreaties leads to overbold conclusions. Sharing the same reading list in school also should not be enough of a premise to justify killing. The same thing is true of land...". ${ }^{2}$

Faludi questions territoriality even though, or perhaps because, he is aware that "territorialism shapes our very perception of the world" (Faludi 2018: 35). Territoriality, in Faludi's interpretation, refers to "states securing their borders and executing jurisdiction within them" (Faludi 2018: 43) i.e. a "mosaic of spatial containers", delimited by the formally approved or arranged borders and the space that fills them seamlessly (Faludi 2018: 3 ). Those containers form hierarchical structures of territorial constituencies on various geographical scales (from local to national), which produce and provide democratic legitimacy for the exercise of power. No territory is without authority. The result is the monopoly of a territorial representative over the production of democratic legitimacy (Faludi 2018: 128). Territorialism implies "a unique set of policies suitable for the territory concerned and its inhabitants in their unique geopolitical and historic settings" (Faludi 2018: 48). By extending this reasoning, one can easily arrive at the conclusion that the only way forward for sustaining the EU is via representative democracy at the level of the Union, or in the shape of a unitarian or federal state. However, as Faludi warns us, this might represent a dead end for the European project.

Territory is an imminent attribute of a nation, in economic, political and symbolic terms. Faludi underlines this in his book, in line with the Herbert's reasoning, i.e. the historical contingency of nations and nationalism (Faludi 2018: 46). Thus, Faludi (2018: 54) argues that "territorialism has its downsides, with ownership, representation and framing implying exclusion". It also fits poorly into the essence of the network society that acts through different functional relations on various geographical scales. Moreover, territoriality diminishes the efficiency of implementation of key EU concepts and values, such as subsidiarity and functional relations, which do not fit into administrative borders (Faludi 2018: 65). Territorialism is dysfunctional, since the home ranges of people do not coincide with constituencies as delimited geographically.

Faludi is aware of all this, but he also knows that change will not be easy. He has a great deal of sympathy for the "Copernican revolution" proposed by Zielonka (2014), as a useful trope for the change of thinking about the EU from a nascent federal state to a new, postmodern type of organisation. But in fact Faludi argues for more subtle, i.e. evolutionary rather than revolutionary changes. In several places, he acknowledges the benefits of the territorial approach in terms of securing international order, as well as providing security and a sense of identity (Faludi 2018: 21). Therefore his main suggestion includes the setup of zones of authority with overlapping boundaries that resemble a medieval type of governance functioning more via incentives and rules than via fixed boundaries. Functional interdependency seems to lay the foundations for this proposal, which overlap territorial units. Thus, the essence of the idea here lies in the combining of territorial and functional representation. The results are territories with enclosing borders (abso-

\footnotetext{
${ }^{2}$ Polish version: Z faktu używania tych samych przekleństw i podobnych zaklęć miłosnych wyciaga się zbyt śmiałe wnioski także wspólna lektura szkolna nie powinna stanowić przesłanki wystarczajq̨cej aby zabić podobnie ma się sprawa z ziemiq...
} 
lute spaces), complemented by numerous overlapping relative spaces. It is in this way that Faludi subscribes to the proposal from Zielonka (2014: 48) whereby more Europes are to be created, rather than more Europe. The EU should become a meta-governor which provides rules and room for negotiations for its active agents within various networks. European agencies may take care of pan-European problems, but do not need to work under hierarchical supervision. Faludi uses several metaphors to describe such an arrangement, comparing Europe to the space occupied by islands in an archipelago, to ice floats drifting in the Arctic, or to swirling clouds.

While Faludi has no ready-made blueprints, he remains convinced that political institutions are past the age of territorialism. The key message is that the existing institutional set up should be adapted to the functional reality, and the current global network, though this may seem difficult (even being described by Zielonka as a "vale of tears"). Here, spatial planners might play an important role by embracing and promoting the functional realm as they do now, on a smaller scale. Their know-how as regards the facilitation of complex processes might prove to be of key importance with this aim in mind.

While all this information is very appealing, the reader remains puzzled as to the exact key mechanism that will ensure that such a negotiation does not ultimately turn into a mere power exercise for well-organised vested interests. It is unclear what this "Holy Grail", that will make people concentrate on "generality, a kind of immanent truth", will be. Faludi most definitely raises an important question that needs more conscious examination. The present governance system does not match up to current dynamic changes in society, as is evident in many spheres, not least the economic division of labour (globalisation), climate change, and limits to growth. Space is part of this picture since, by definition, it is constituted by natural and human interactions, the latter having changed entirely by taking on a more functional character.

Faludi challenges our schematic thinking, but this inspiration is not without caveats. First of all, to my way of thinking, the parallel with the Law of the Sea (UNCLOS), as a framework governing the life of the archipelago remains largely uninformative. Being a maritime spatial planner, I observe territoriality even of the High Seas. This is not because of greedy coastal states, but rather reflects the acceleration of those spatial conflicts that the general rules of UNCLOS do not prevent (Altvater at al. 2019). Such conflicts and failures can easily sink the entire archipelago. Who should prevent that? Can spatial planners play an important role here? The issue of High-Sea maritime spatial planning remains open. It is probable that it will be based on negotiations between sovereign states, visionary statements and general principles (in some form of the agreement), but one can easily imagine here, at the end of the day, some quasi-territorial borders, in terms of permits and licences. Thus, a key question for an archipelago metaphor is rather how to provide a kind of democratic legitimacy for fair access to marine resources, and how to define this fair access in practice. The case of the Nord Stream gas pipeline shows how difficult this may be both under territorial and functional arrangements (when huge money ends up talking).

Secondly, an imminent feature of a networking form of governance is the sharing and managing of information. And nowadays this creates some serious problems, such as irresponsible information release, information manipulation and the influencing of dispersed human decision-making through the targeting of groups of people with information zombies. Neither territorial nor non-territorial governance arrangements can cope with this. Thus, for the sake of the future of the European project, we need other mechanisms that will prove able to prevent aggressive or short-sighted, rent-seeking information-related actions. Otherwise, the European Archipelago will be lost. It is unclear to me to what extent the weakening of territorialism might help. Perhaps it might, but only if conducted on a global scale. But even in that case, the power of the major eco- 
nomic players will remain intact. Will islands be able to oppose their dominance? Perhaps Faludi's ideas should be continued with, and extended in that direction, by other social-science scholars?

Thirdly, Faludi's ideas might be difficult for some East European nations to swallow, and the author is aware of this (2018: 137). In Poland, national sovereignty is still very much appreciated, since thousands of Poles have paid a high price for it. In a potentially harsh economic situation, the majority of Poles would expect to be rescued by the nation state. Although this may not necessarily be rational, it remains a fact that Poles appreciate the presence of their own territorial containers. They can accept better linkages between them, as well as a territorial impact assessment of their actions, but their dominant governing position seems to be an axiom. Territorial governments are considered part of the great success of Poland's transformation, which denotes simultaneously the successful elimination of the legacy of central planning. But perhaps a reasonable compromise is knocking on the door, in the form of a quote from Timmermans that is close to both my heart and that of Andreas, namely: "You can be proud of something - like one's language and culture - but still be cooperative, and this precisely because you have something to be proud of".

While Faludi proposes a combination of territorial and functional representation, it would seem that each European society might have such a combination all of its own, in line with its values and historical experience. How, then, would this work for all? Are we ready to absorb the risk that testing out this plan denotes? In other words, do we have a contingency plan to alleviate potential negative consequences of an action possibly proving to be of the same magnitude as the establishment of the Eurozone which, because it did not rationalize the decisions of certain nations, ended up pushing the latter into a corner? The risk is high, i.e. diminished trust in the EU and eroded legitimacy of decision-making at European level. Neither national territorialism, nor functional representation offers the right answers to such dilemmas. However, usual suspects, like education and research, might perhaps help.

Fourthly, Faludi argues against territoriality in what is seemingly a well-justified concern. However, by the same token, the book might erode sympathy for such concepts as policy territorialisation or territorial cohesion, since a territorial component is also crucial there. And since such notions would seem to be of key importance to any transformation of the EU in the direction of a relational archipelago, the book may serve to weaken the foundations upon which the whole transformation concept is built up.

In conclusion, I would like to convince those who care about the future of our continent to read Faludi's book, as a truly great source of inspiration and fresh thinking on the spatial domain. Faludi is absolutely correct in his claim that space invokes governance, with territorial cohesion having a clear governance dimension. So this book will definitely initiate a Europe-wide discourse, and in contributing thereto - I would like to join Zbigniew Herbert in his concluding stance. The poet is unable to give precise advice as to what to do, but merely confirms the severity of the problem by saying: "so at last in the form of a testament that it might be known: I rebelled but I think this blood-stained knot should be the last one that he who struggles to break away, tears apart."

Having said that, I must admit that I do have a great deal of sympathy for Faludi, when he likewise indicates the problem, without necessarily insisting upon an immediate and radical solution. 


\section{References}

Altvater S., Fletcher R., Passarello C., 2019. The Need for Marine Spatial Planning in Areas Beyond National Jurisdiction. [in:] J. Zaucha, K. Gee (eds.) Maritime Spatial Planning, past, present, future. Palgrave, London, pp. 397-415.

Faludi A., 2007. The European Model of Society. [in:] A. Faludi (ed.) Territorial Cohesion and the European Model of Society, Cambridge MA: Lincoln Institute of Land Policy, pp. 1-22.

Faludi A., 2010. Cohesion, coherence, cooperation: European spatial planning coming of age? London: Routledge.

Faludi A., 2018. The Poverty of Territorialism. A Neo-Medieval View of Europe and European Planning. Cheltenham, Northampton: Edward Elgar.

Zielonka J., 2014. Is the EU Doomed? Cambridge: Polity Press. 